\title{
CULTURA, SABERES E DISCIPLINAS ESCOLARES NA IBERO-AMÉRICA
}

Maria do Carmo Martins ${ }^{1}$

O quarto número da revista Educação Temática Digital - ETD é lançado ainda em meio às incertezas sobre o retorno dos estudantes às atividades escolares, antes consideradas regulares. $\mathrm{O}$ vírus Sars Cov2 e a pandemia que a ele se associa modificaram, nesse estranho ano de 2020, o cotidiano de todas as pessoas. No caso das crianças e jovens que frequentam as escolas, tais modificações foram marcadas pelo distanciamento físico dos colegas, pela perda da vivência no espaço escolar e por uma profusão de atividades mediadas por uma tecnologia assombrosa e sedutora, produzindo distintas sensações e pertencimentos ao mundo.

Dentre as experiências cotidianas que foram remexidas nessa condição excepcional de confinamento das pessoas aos seus espaços domésticos, as práticas culturais que ocorrem na escola, o ofício do professor e a finalidade social e política da educação escolar figuram nos mais calorosos debates, seja pela expectativa de um retorno gradual e seguro às atividades correntes, seja pelos desdobramentos de uma retórica de mudança como imperativo para o futuro da educação.

É nesse contexto de um presente incerto e um futuro imaginado que publicamos um dossiê histórico sobre a Cultura, Saberes e Disciplinas escolares na Ibero-América, cuja principal função não é enfatizar relatos sobre eventos pretéritos, mas, articular o presente com o passado, visando um lembrar ativo e uma ressignificação histórica do ensino e das práticas diversas que constituem a experiência escolar.

O dossiê, proposto pelos pesquisadores colombianos Alejandro Alvarez, Rafael Ríos e Miguel Angel Martínez é composto por sete artigos e uma apresentação, sendo majoritariamente publicado em espanhol. Apresentam resultados de pesquisas realizadas sobre a história da educação ibero-americana e contextualizam a proposta em diálogos de historiadores que se encontram em eventos dessa comunidade regional. Como condição especial em nossa política editorial e, visando a organicidade da proposta, inserimos nesta edição uma tradução, para o espanhol, de um artigo de Anne-Marie Chartier originalmente publicado em francês e considerado referencial para os debates nessa comunidade.

\footnotetext{
${ }^{1}$ Doutora em Educação - Universidade Estadual de Campinas (UNICAMP). Campinas, SP - Brasil. Professora livre-docente - Universidade Estadual de Campinas (UNICAMP). Campinas, SP - Brasil.

E-mail: carminhapousa@gmail.com
}
(C) ETD- Educação Temática Digital
Campinas, SP
v. 22
n.4
p.784-786
out./dez. 2020 
Em seu conjunto, os artigos concretizam a problematização de noções, conceitos e metodologias na abordagem da cultura, do currículo, dos saberes e das disciplinas escolares buscando, em cada um, ampliar e diversificar as perspectivas sobre esses elementos em diálogo com outros estudos presentes na historiografia da educação. Na apresentação do dossiê, os proponentes destacam a importância dos artigos para repensarmos a escola como acontecimento de saber e de poder. Deste modo, sua composição nos conduz a abraçar os desafios epistemológicos e metodológicos das pesquisas históricas que reiteram a escola segundo esta premissa.

Assim como os propositores, confiamos que os artigos nos possibilitam repensar a história da escola e do ensino não como uma continuidade, mas percebendo as descontinuidades como potencializadoras, uma vez que estas se tornaram elementos fundamentais da análise histórica. Como indica Foucault (2000), aos historiadores contemporâneos se colocam interrogações muito mais difíceis do que estabelecer ligações entre acontecimentos descontínuos. A eles cabe isolar estratos, definir tipo e critério para outras periodizações e perceber os sistemas de relações que podem ser descritos nesses estratos isolados. Uma parte dos artigos do dossiê se assenta em abordagem foucaultiana, sendo perceptível o esforço dos autores ao enfrentarem essas questões com grande seriedade.

Ainda neste número da Revista outros seis artigos de demanda contínua estão disponíveis para apreciação das leitoras e leitores da ETD, além de uma entrevista com o sociólogo francês Christian Laval, na qual a "nova escola capitalista" é colocada em evidência.

Há artigos que versam sobre tecnologias e educação, pensadas como recursos em curso de formação de professores e analisadas, criticamente, no âmbito das relações sociais contemporâneas. Destacam-se por suas abordagens atuais e por fornecerem elementos aos professores, pesquisadores da educação e das ciências sociais para que construam referências quanto as demandas educacionais do tempo presente.

Em um artigo sobre a construção da noção social da greve entre estudantes de faixas etárias distintas, inseridos em escolas públicas e privadas, procura-se compreender como tais estudantes constroem a percepção da realidade diante dos eventos como as greves estudantis.

Damos destaque, ainda, ao artigo que reflete sobre oficinas realizadas com estudantes, visando proliferar pensamentos sobre questões étnico-raciais e potencializar as experiências de conviver. Neste artigo a arte, a educação e a antropologia são emaranhadas

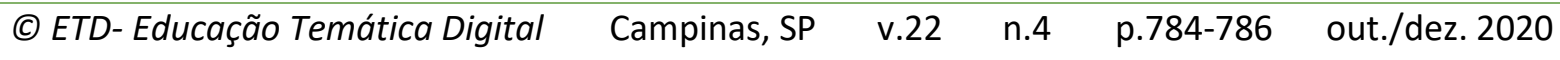


e as produções das imagens, assim como as reflexões sobre os significados dos encontros, são apresentadas ao leitor e à leitora de maneira bastante propositiva.

Desejamos que todas e todos aproveitem as leituras e reiteramos nossos anseios de que estejamos dispostos a ampliar as redes de solidariedade, visando com elas a amplificação dos cuidados com a vida nesse momento adverso. Ansiamos também que novos tempos cheguem acompanhados de boas notícias.

\section{REFERÊNCIAS}

FOUCAULT, Michel. Sobre a Arqueologia das ciências. Resposta ao círculo de Epistemologia. Arqueologia das Ciências e história dos sistemas de pensamento (organização e seleção de textos Manoel Barros da Motta). Rio de Janeiro: Forense Universitária, 2000. 